University of Nebraska - Lincoln

DigitalCommons@University of Nebraska - Lincoln

Faculty Publications: Department of

Entomology

Entomology, Department of

2-1-2006

Physiological Responses of Resistant and Susceptible

Buffalograsses to Blissus Occiduus (Hemiptera: Blissidae)

Feeding

\author{
Tiffany Heng-Moss \\ University of Nebraska-Lincoln, thengmoss2@unl.edu \\ Tulio Macedo \\ Montana State University, Bozeman, MT \\ Lisa Franzen-Castle \\ University of Nebraska-Lincoln, Ifranzen2@unl.edu \\ Frederick P. Baxendale \\ University of Nebraska-Lincoln, fbaxendale1@unl.edu \\ Leon G. Higley \\ University of Nebraska-Lincoln, Ihigley1@unl.edu \\ See next page for additional authors
}

Follow this and additional works at: https://digitalcommons.unl.edu/entomologyfacpub

Part of the Entomology Commons

Heng-Moss, Tiffany; Macedo, Tulio; Franzen-Castle, Lisa; Baxendale, Frederick P.; Higley, Leon G.; and Sarath, Gautam, "Physiological Responses of Resistant and Susceptible Buffalograsses to Blissus Occiduus (Hemiptera: Blissidae) Feeding" (2006). Faculty Publications: Department of Entomology. 121. https://digitalcommons.unl.edu/entomologyfacpub/121

This Article is brought to you for free and open access by the Entomology, Department of at DigitalCommons@University of Nebraska - Lincoln. It has been accepted for inclusion in Faculty Publications: Department of Entomology by an authorized administrator of DigitalCommons@University of Nebraska - Lincoln. 


\section{Authors}

Tiffany Heng-Moss, Tulio Macedo, Lisa Franzen-Castle, Frederick P. Baxendale, Leon G. Higley, and Gautam Sarath 


\title{
Physiological Responses of Resistant and Susceptible Buffalograsses to Blissus Occiduus (Hemiptera: Blissidae) Feeding
}

\author{
TIFFANY HENG-MOSS, TULIO MACEDO, ${ }^{1}$ LISA FRANZEN, FREDERICK BAXENDALE, \\ LEON HIGLEY, AND GAUTAM SARATH ${ }^{2}$
}

Department of Entomology, University of Nebraska, Lincoln, NE 68583

J. Econ. Entomol. 99(1): 222-228 (2006)

\begin{abstract}
The impact of Blissus occiduus Barber feeding on resistant ('Prestige') and susceptible ('378') buffalograsses, Buchloë dactyloides (Nuttall) Engelmann, was evaluated through measurement of carbon exchange rate, light and carbon assimilation $\left(\mathrm{A}-\mathrm{C}_{\mathrm{i}}\right)$ curves, chlorophyll $a$ fluorescence, and nonstructural carbohydrates. No significant differences in carbon exchange rates were observed between infested and control plants for 378 at 5 and $10 \mathrm{~d}$ after infestation; however, at $20 \mathrm{~d}$ after chinch bug introduction, significant differences in carbon exchange rates between infested and control 378 plants were detected. Carbon exchange rates were similar between infested and control Prestige plants at 5,10 , and $20 \mathrm{~d}$ after infestation, suggesting that resistant plants can allocate energy for recovery from chinch bug injury. Significant differences in the photochemical efficiency of photosystem II (PSII) and the apparent photosynthetic electron transport ratio were observed between infested and control 378 plants, whereas, no significant differences in the photochemical efficiency of PSII and the electron transport ratio were detected between control and infested Prestige plants. Blissus occiduus-infested 378 and Prestige plants consistently had similar or higher levels of nonstructural carbohydrates compared with their respective control plants. These data suggest that both resistant and susceptible buffalograsses increase levels of nonstructural carbohydrates in response to B. occiduus feeding. This research also suggests compensatory photosynthesis takes place in Prestige but not in 378 .
\end{abstract}

KEY WORDS buffalograss, Blissus occiduus, carbon exchange rates, nonstructural carbohydrates, fluorescence kinetics

Buffalograss, Buchloë dactyloides (Nuttall) Engelmann, has received considerable attention as an alternative turfgrass species because of its low maintenance requirements and excellent drought tolerance. Although few arthropods are injurious to buffalograss, the western chinch bug, Blissus occiduus Barber, has emerged as an important insect pest of this warm-season grass (Baxendale et al. 1999). Studies have been conducted to evaluate selected buffalograss germplasm for resistance to B. occiduus. Greenhouse and field studies identified the buffalograsses 'Prestige' (previously reported as NE91-118), 'Cody', and 'Tatanka' as highly to moderately resistant to B. occiduus (Heng-Moss et al. 2002). Studies designed to determine levels of tolerance, antibiosis, and antixenosis among these resistant buffalograsses characterized Prestige, Cody, and Tatanka as tolerant (Heng-Moss et al. 2003).

When developing insect-resistant turfgrasses, a thorough understanding of the underlying mecha-

\footnotetext{
${ }^{1}$ Department of Entomology, Montana State University, Bozeman, MT 59717.

${ }^{2}$ USDA-ARS, Department of Agronomy, University of NebraskaLincoln, Lincoln, NE 68583-0937.
}

nisms for resistance is important for formulating optimal strategies for identifying and exploiting new sources of resistance. Although considerable progress has been made in identifying germplasm resistant to insect pests, progress toward characterization of the physiological and biochemical mechanisms conferring the resistance has been limited.

Understanding how chinch bug feeding affects the plant's physiology (e.g., carbon exchange rates and changes in nonstructural carbohydrates) may help to explain physiological mechanisms underlying plant tolerance. Studies (Welter 1989; Peterson and Higley 1993; Peterson et al. 1996, 1998) have assessed the impact defoliating insects have on carbon exchange rates; however, relatively few studies (Ryan et al. 1987, Haile et al. 1999, Macedo et al. 2003) have focused on sap-feeding insects and the possible role of changes in carbon exchange processes as a mechanism for plant tolerance to insect injury. The objectives of this study were to investigate changes in carbon exchange rates, chlorophyll $a$ fluorescence kinetics, and levels of nonstructural carbohydrates between resistant and susceptible buffalograsses responding to feeding by $B$. occiduus. 


\section{Materials and Methods}

Physiological Responses of Buffalograsses to B. Occiduus Feeding. Plants and Insects. This study investigated the physiological responses of resistant (Prestige) and susceptible ('378') buffalograss to B. occiduus. Plugs of Prestige and $378,10.6 \mathrm{~cm}$ in diameter by $6 \mathrm{~cm}$ in depth, were extracted from buffalograss evaluation plots at the John Seaton Anderson Turfgrass and Ornamental Research Facility (JSA Facility), University of Nebraska Agricultural Research and Development Center, near Mead, NE. Plugs were trimmed to the soil surface, and individual buffalograss plants were extracted and planted in 'SC-10 Super Cell' Single Cell Cone-tainers $(3.8 \mathrm{~cm}$ in diameter by $21 \mathrm{~cm}$ in depth) (Stuewe \& Sons, Inc. Corvallis, OR) containing a potting mixture of sand-soil-peat-perlite in a 0.66:0.33:1:1 ratio, and placed under 400-W highintensity density lamps with a photoperiod of 16:8 (L:D) h for $4 \mathrm{wk}$ before beginning the study. Conetainers were placed in seven by 14 Cone-tainer trays. Plants were fertilized biweekly with a soluble 20.0: 4.4:16.6 (N20-P10-K20) fertilizer. The experiment was conducted in a greenhouse maintained at $28 \pm$ $2^{\circ} \mathrm{C}$. At bench height, light intensity with supplemental lighting averaged $1,150 \mu \mathrm{mol}$ photons $\mathrm{m}^{-2} \mathrm{~s}^{-1}$.

B. occiduus were collected from an infested 378 plot at the JSA Facility. Insects were held in the laboratory for $24 \mathrm{~h}$ before beginning the study to eliminate individuals injured or killed during the collection process. At the start of the study, plants were paired according to similar blade heights and turf quality. Ten chinch bugs were introduced on one plant of each buffalograss pair, whereas the other plant served as the uninfested control. Tubular, Plexiglas cages $(4 \mathrm{~cm}$ in diameter by $30 \mathrm{~cm}$ in height) served to confine chinch bugs on the plant. The same type of cage was also placed on the noninfested plants, ensuring that the same environment was provided for all plants.

Chinch bugs were removed from the test plants at 5,10 , and $20 \mathrm{~d}$ after infestation. Plants were rated for chinch bug damage using a 1-5 scale, where 1 is $10 \%$ or less damage; 2 is 11 to $30 \%$ damage; 3 is 31 to $50 \%$ damage; 4 is 51 to $70 \%$ damage; and 5 is $71 \%$ or more damage and plant close to death (Heng-Moss et al. 2002).

The experimental design was a completely randomized design with six replications. The treatment design was a 2 by 2 by 3 factorial experiment (two buffalograsses, two levels of chinch bug infestation, and three sample dates), and the experimental unit was a plant.

Carbon Exchange Rates. Carbon exchange rates of the buffalograsses were recorded at 5, 10, and $20 \mathrm{~d}$ after chinch bug introduction by using a portable photosynthesis system (model LI-6400, LI-COR, Lincoln, NE) (Peterson et al. 1996, 1998; Haile et al. 1999; Macedo et al. 2003). Leaf area was determined and entered in the LI-6400's automated program to adjust carbon exchange rates for the leaf area of the sampled blade. Carbon exchange rates were measured at 400 $\mu \mathrm{mol} \mathrm{CO}_{2} \mathrm{~mol}^{-1} \mathrm{CO}_{2}$ concentration and 2,000 $\mu \mathrm{mol}$ photons $\mathrm{m}^{-2} \mathrm{~s}^{-1}$ light intensity.

Chlorophyll a Fluorescence Kinetics. Chlorophyll a kinetic transients were measured in the same injured area (on the adaxial surface) at the same time as carbon exchange rates. These parameters were measured using an OS5-FL modulated chlorophyll fluorometer (Optic-Sciences, Tyngsboro, MA).

Nonstructural Carbohydrate Determination. Nonstructural carbohydrate concentrations were quantified by determining reducing sugar concentrations as glucose equivalents present in the plant material. After storage at $-80^{\circ} \mathrm{C}$, plant material was dried at $70^{\circ} \mathrm{C}$ in a forced draft oven for $48 \mathrm{~h}$ and then mechanically ground. Twenty-five $\mathrm{ml}$ of $0.02 \mathrm{M}$ benzoic acid was added to a Folin-Wu tube containing a small sample (10 mg) of the material. The sample was placed in an autoclave for $20 \mathrm{~m}$ on the liquid cycle and slow cooled. The autoclaving step was repeated one additional time to ensure nonstarch oligosaccharides and polysaccharides were hydrolyzed. Approximately $500-\mu$ l aliquots were then diluted to $750 \mu \mathrm{l}$ with $50 \mathrm{mM}$ potassium acetate, $\mathrm{pH} 5$, and $0.02 \mathrm{M}$ benzoic acid. Two-hundred and fifty microliters of an amylase/amyloglucosidase was added to the solution, which was then incubated at $42^{\circ} \mathrm{C}$ for $15 \mathrm{~h}$. The solution was then assayed for total extractable carbohydrate according to the NelsonSomogyi copper reducing method (Somogyi 1952). The specific amount of glucose equivalents was quantified by measuring the absorbency of $\mathrm{Cu}_{2} \mathrm{O}$ at $600 \mathrm{~nm}$ by using a spectrophotometer. Known concentrations of glucose were used to generate a standard curve.

Data Analyses. Data were analyzed using mixed model analysis (PROC MIXED, SAS Institute 1997) to detect differences in carbon exchange rates, fluorescence parameters, and nonstructural carbohydrates between $B$. occiduus-resistant and -susceptible buffalograsses (Littell et al. 1996). When appropriate, means were separated using Fisher's least significant difference (LSD) procedure.

Physiological Recovery of Chinch Bug Injury in Buffalograss. Plants and Insects. A second study was conducted to investigate the ability of resistant (Prestige) and susceptible (378) buffalograsses to recover from $B$. occiduus feeding. Sod plugs were collected from buffalograss plots, planted, and maintained as discussed above.

B. occiduus were collected from an infested 378 plot at the JSA Facility. Chinch bugs were held in the laboratory for $24 \mathrm{~h}$ before beginning the study. At the start of the study, plants were paired according to similar heights and turf quality. Eight chinch bugs were introduced on one plant of each buffalograss pair, whereas the other served as the uninfested control. Tubular Plexiglas cages $(4 \mathrm{~cm}$ in diameter by 30 $\mathrm{cm}$ in height) confined chinch bugs on the plants. The same type of cage also was placed on the noninfested plants, ensuring that the same environment was provided for all plants. The experimental design was a completely randomized design with eight replications, and the experimental unit was a plant. 
Chinch bugs were removed from the test plants $14 \mathrm{~d}$ after infestation. Plants were rated for chinch bug damage at this time using a 1-5 scale, where 1 is $10 \%$ or less damage; 2 is 11 to $30 \%$ damage; 3 is 31 to $50 \%$ damage; 4 is 51 to $70 \%$ damage; and 5 is $71 \%$ or more damage and plants are close to death (Heng-Moss et al. 2002).

Carbon Exchange Rates. Carbon exchange rates of the buffalograsses were recorded at $3,24,48$, and $72 \mathrm{~h}$ after chinch bug removal by using a portable photosynthesis system. Leaf area was determined and entered in the LI-6400's automated program to adjust carbon exchange rates for the leaf area of the sampled blade. Three types of carbon exchange measurements were performed: carbon exchange measurements (rates measured at 2,000 $\mu \mathrm{mol}$ of photons $\mathrm{m}^{-2} \mathrm{~s}^{-1}$ light intensity and $400 \mu \mathrm{mol} \mathrm{CO} \mathrm{Col}^{-1} \mathrm{CO}_{2}$ concentration), light curves (rates measured at light intensities ranging from 0 to $2,000 \mu \mathrm{mol}$ photons $\mathrm{m}^{-2} \mathrm{~s}^{-1}$ ), and carbon assimilation $\left(\mathrm{A}-\mathrm{C}_{\mathrm{i}}\right.$ ) curves (rates measured at $\mathrm{CO}_{2}$ concentrations ranging from 0 to 1,000 $\mu \mathrm{mol} \mathrm{CO}{ }_{2}$ mol $\left.^{-1}\right)$. Light and $\mathrm{A}-\mathrm{C}_{\mathrm{i}}$ curves were determined by the automated programs of the LI-6400.

Data Analyses. Data were analyzed using mixed model analysis (PROC MIXED, SAS Institute 1997) to detect differences in carbon exchange rates between chinch bug-resistant and -susceptible buffalograsses (Littell et al. 1996). When appropriate, means were separated using Fisher's LSD procedure.

\section{Results and Discussion}

Physiological Responses of Buffalograsses to B. Occiduus Feeding. No visual evidence of chinch bug damage was observed on infested 378 and Prestige plants at $5 \mathrm{~d}$ after chinch bug infestation. Chinch bug-infested Prestige plants continued to show no visible chinch bug damage on day 10 (damage rating 1.0 ) and 20 (damage rating $1.5 \pm 0.2$ ), whereas chinch bug-infested 378 plants had damage ratings of $1.8 \pm 0.2$ and $3.1 \pm 0.2$ on day 10 and 20 , respectively $(F=15.6$; $\mathrm{df}=2,30 ; P=0.0001)$.

Carbon Exchange Rates. No significant differences in carbon exchange rates were observed between infested and control plants for 378 at 5 and $10 \mathrm{~d}$ after chinch bug infestation (day $5: t=3.94, \mathrm{df}=10, P=$ 0.54; day 10: $t=0.33, \mathrm{df}=10, P=0.75$ ) (Table 1). However, at $20 \mathrm{~d}$ after chinch bug infestation, significant differences in carbon exchange rates between infested and control 378 plants were observed $(t=3.3$, $\mathrm{df}=10, P=0.01)$. At $20 \mathrm{~d}$ after chinch bug infestation, there was a $66 \%$ reduction in activity for the infested plants compared with control plants. Carbon exchange rates were similar between infested and control Prestige plants at 5, 10, and $20 \mathrm{~d}$ after chinch bug infestation $(F=0.79$; $\mathrm{df}=1,10 ; P=0.40)$. It is interesting to note that infested Prestige plants had activity levels similar to uninfested control plants at $20 \mathrm{~d}$ after chinch bug introduction. These data suggest that compensatory photosynthesis was occurring in the resistant Prestige but not in the susceptible 378 plants.
Table 1. Carbon exchange rates of resistant and susceptible buffalograsses at 5, 10, and $20 \mathrm{~d}$ after chinch bug infestation

\begin{tabular}{|c|c|c|c|}
\hline \multirow[t]{2}{*}{ Buffalograss } & \multicolumn{2}{|c|}{$\begin{array}{c}\text { Mean } \pm \text { SEM carbon } \\
\text { exchange rate } \\
\left(\mu \mathrm{mol} \mathrm{CO} \mathrm{m}^{-2} \mathrm{~s}^{-1}\right)\end{array}$} & \multirow[t]{2}{*}{$\%^{a}$} \\
\hline & Control & Infested & \\
\hline \multicolumn{4}{|c|}{$5 \mathrm{~d}$ after infestation } \\
\hline Prestige & $12.4 \pm 1.9 \mathrm{a}$ & $18.2 \pm 5.1 \mathrm{a}$ & \\
\hline 378 & $18.7 \pm 2.8 \mathrm{a}$ & $16.5 \pm 1.6 \mathrm{a}$ & 11.7 \\
\hline \multicolumn{4}{|c|}{$10 \mathrm{~d}$ after infestation } \\
\hline Prestige & $12.7 \pm 3.4 \mathrm{a}$ & $13.2 \pm 1.4 \mathrm{a}$ & \\
\hline 378 & $11.4 \pm 2.3 \mathrm{a}$ & $9.1 \pm 3.2 \mathrm{a}$ & 20.2 \\
\hline \multicolumn{4}{|c|}{$20 \mathrm{~d}$ after infestation } \\
\hline Prestige & $10.9 \pm 1.9 \mathrm{a}$ & $9.2 \pm 2.6 \mathrm{a}$ & 15.6 \\
\hline 378 & $14.7 \pm 2.3 \mathrm{a}$ & $5.0 \pm 2.9 \mathrm{~b}$ & 66.0 \\
\hline
\end{tabular}

Means in the same row followed by the same letter are not significantly different $(P>0.05$, LSD test).

${ }^{a}$ Percentage of reduction in carbon exchange rate resulting from B. occiduus injury relative to the control treatment.

Chlorophyll a Fluorescence Kinetics. Significant differences in the yield of photochemical efficiency of photosystem II (PSII) (378: $t=7.5, \mathrm{df}=10, P=0.01$ ) and the photosynthetic electron transport ratio (378: $t=6.4$, df $=10, P=0.02$ ) were observed between infested and control 378 plants at $20 \mathrm{~d}$ after chinch bug infestation. Five days after chinch bug infestation, infested and control 378 plants had similar photochemical efficiency rates (control 193.8 \pm 8.6 , infested $177.5 \pm 9.4)(t=1.3, \mathrm{df}=10, P=0.12)$ and electron transport ratios (control $0.42 \pm 0.1$, infested $0.38 \pm$ 0.09) $(t=1.7, \mathrm{df}=10, P=0.09)$; however, significant reductions in the photochemical efficiency of PSII (control 213.8 \pm 8.3, infested 138.3 \pm 9.7 ) and electron transport ratio (control $0.46 \pm 0.1$, infested $0.30 \pm$ $0.09)$ were detected at $20 \mathrm{~d}$ after chinch bug introduction. No significant differences in the photochemical efficiency of PSII (day $5: t=0.33, \mathrm{df}=10, P=0.38$; day $20: t=1.9, \mathrm{df}=10, P=0.74)$ and the photosynthetic electron transport ratio (day $5: t=0.1, \mathrm{df}=10$, $P=0.75$; day $20: t=0.4, \mathrm{df}=10, P=0.54$ ) were detected between control and infested Prestige plants. Additionally, chinch bug feeding had no significant effect on the quenching coefficients and other fluorescence parameters (minimal fluorescence $\left[\mathrm{F}_{\mathrm{o}}\right]$, maximal fluorescence $\left[\mathrm{F}_{\mathrm{m}}\right]$, and steady-state and maximal steady-state fluorescence $\left[\mathrm{F}_{\mathrm{s}}\right.$ and $\left.\mathrm{F}_{\mathrm{ms}}\right]$ ) measured.

Nonstructural Carbohydrate Determination. Significant differences were detected between the nonstructural carbohydrate levels for the infested and control 378 plants beginning at $10 \mathrm{~d}$ after chinch bug infestation $(F=9.0 ; \mathrm{df}=1,10 ; P>0.0001)$ (Fig. 1). Infested 378 plants consistently had higher nonstructural carbohydrate levels than control plants. Nonstructural carbohydrate levels were similar between infested and control Prestige plants at 5 and $10 \mathrm{~d}$ after chinch bug infestation; however, by $20 \mathrm{~d}$ after chinch bug infestation significant differences were observed $(F=11.41 ; \mathrm{df}=1,10 ; P>0.004)($ Fig. 2$)$. These results suggest that buffalograss plants respond to chinch bug feeding in the long-term by maintaining a greater 


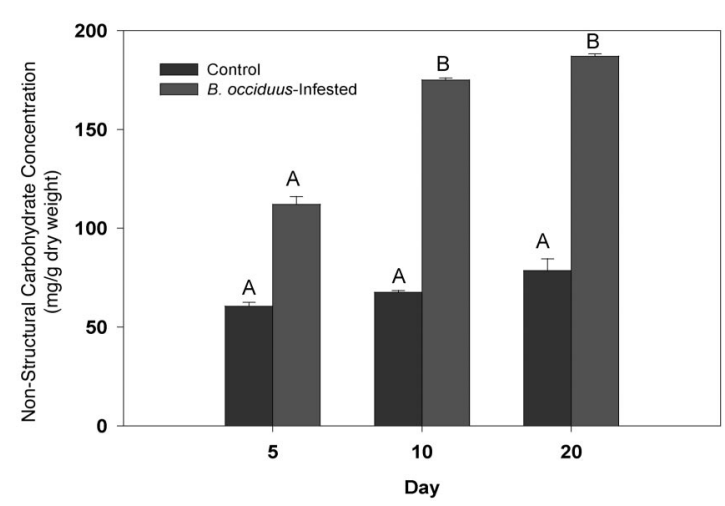

Fig. 1. Nonstructural carbohydrate concentrations of chinch bug-infested and noninfested susceptible buffalograss (378) at 5, 10, and $20 \mathrm{~d}$ after chinch bug removal. Bars with the same letter are not significantly different $(P>0.05)$.

proportion of photosynthate as nonstructural carbohydrates. The susceptible germplasm 378 is unable to maintain adequate photosynthetic rates under chinch bug pressure eventually leading to extensive plant damage. In contrast, the resistant Prestige plants apparently compensated for chinch bug injury through enhanced photosynthesis, and as a result sustained lower amounts of injury. Data from chlorophyll fluorescence support this hypothesis; however, the mechanisms controlling global enhancement of nonstructural carbohydrates in response to chinch bug feeding are not known. Our chlorophyll fluorescence data show significant reductions in the efficiency of the photochemical reactions of susceptible plants after exposure to chinch bugs. Reductions in the overall photochemical quantum yield and on the apparent photosynthetic electron transport rate were observed after prolonged chinch bug feeding, and corresponded with a $66 \%$ reduction in the photosynthetic capacity of injured 378 plants. These data strongly support photosynthetic compensatory mechanisms as an underlying source of resistance in buffalograss.

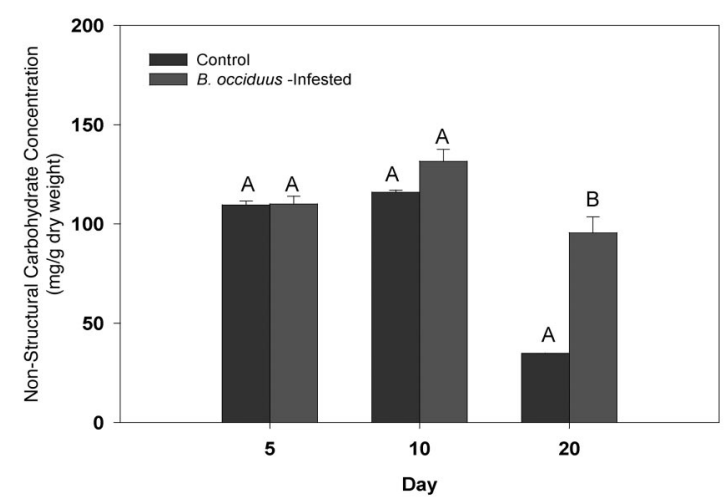

Fig. 2. Nonstructural carbohydrate concentrations of chinch bug-infested and noninfested resistant buffalograss (Prestige) at 5, 10, and $20 \mathrm{~d}$ after chinch bug removal. Bars with the same letter are not significantly different $(P>0.05)$.
The lack of an effect on other fluorescence parameters (i.e., $\mathrm{F}_{\mathrm{o}}, \mathrm{F}_{\mathrm{m}}, \mathrm{F}_{\mathrm{s}}$, and $\mathrm{F}_{\mathrm{ms}}$ ) suggests that reductions in the photosynthetic capacity of infested plants is not directly related to the blockage of electron flow through the PSII complex. Based on our $\mathrm{F}_{\circ}$ and quenching coefficients, we also can discount the possibility of size reductions of the quinone pool in infested plants, which would result in accumulation of active oxygen species and disrupt the thylakoid membrane, resulting in chlorophyll content reductions and chlorosis (Burd and Elliott 1996).

The remaining question is, What is causing disruption of the overall photochemical quantum yield and the photosynthetic electron transport rate? Chinch bug injury may be involved with either a modification in the PSII structure (e.g., detachment of the antennal chlorophyll complex from PSII) or with $\mathrm{CO}_{2}$ fixation (Green et al. 1998). Our nonstructural carbohydrate data indicated an increase in concentration of this reducing sugar in infested 378 plants after a few days of chinch bug feeding. This suggests the photosynthetic reductions observed in successive sampling dates may be related to end product inhibition resulting from phloem-loading and -unloading dynamics (Macedo 2003). It also supports the idea that overall photochemical quantum yield and photosynthetic electron transport rates are more involved with $\mathrm{CO}_{2}$ fixation inhibition.

Physiological Recovery of Chinch Bug Injury in Buffalograss. B. occiduus caused visible injury to 378 plants $14 \mathrm{~d}$ after chinch bug introduction, whereas Prestige plants showed no visible damage in response to chinch bug feeding ( $F=22.6 ; \mathrm{df}=1,14 ; P=0.0003)$. The average chinch bug damage rating for 378 was $1.8 \pm 0.08$.

Significant differences in carbon exchange rates were detected between infested and control 378 and Prestige plants at all four evaluation times $(3 \mathrm{~h}: F=5.9$; $\mathrm{df}=1,28 ; P=0.02 ; 24 \mathrm{~h}: F=19.1 ; \mathrm{df}=1,28 ; P=0.0001$; $48 \mathrm{~h}: F=13.6 ; \mathrm{df}=1,28 ; P=0.001$; and $72 \mathrm{~h}: F=7.3$; $\mathrm{df}=1,28 ; P=0.0114)$. Three hours after chinch bug removal, 378 and Prestige plants both exhibited carbon exchange rate reductions in response to chinch bug feeding (Table 2). The level of reduction in carbon exchange rates differed among the resistant and susceptible buffalograsses. At $3 \mathrm{~h}$ after chinch bug removal, the tolerant buffalograss Prestige showed an $11.3 \%$ reduction in activity when compared with its respective control, whereas the chinch bug-susceptible 378 exhibited a $35.4 \%$ reduction in activity compared with its uninfested controls. Infested 378 plants continued to exhibit a significant reduction in carbon exchange rates at 24,48 , and $72 \mathrm{~h}$ after chinch bug removal. Infested Prestige plants, however, exhibited carbon exchange rates similar $(<10 \%$ reduction) to their uninfested controls. In all cases, 378 plants had at least a three-fold increase in percentage of carbon exchange rate reduction compared with their control plants. This study suggests that compensatory photosynthesis takes place in Prestige but not in 378.

Light response curves provided information on the relationship between carbon exchange rates and light 
Table 2. Carbon exchange rates of resistant and susceptible buffalograsses at $3,24,48$, and $72 \mathrm{~h}$ after chinch bug removal

\begin{tabular}{|c|c|c|c|}
\hline \multirow[t]{2}{*}{ Buffalograss } & \multicolumn{2}{|c|}{$\begin{array}{c}\text { Mean } \pm \text { SEM carbon } \\
\text { exchange rate } \\
\left(\mu \mathrm{mol} \mathrm{CO} \mathrm{Cm}^{-2} \mathrm{~s}^{-1}\right)\end{array}$} & \multirow[t]{2}{*}{$\%^{a}$} \\
\hline & Control & Infested & \\
\hline \multicolumn{4}{|c|}{$3 \mathrm{~h}$ after chinch bug removal } \\
\hline Prestige & $24.0 \pm 1.1 \mathrm{a}$ & $21.3 \pm 1.5 \mathrm{a}$ & 11.3 \\
\hline 378 & $22.6 \pm 1.9 \mathrm{a}$ & $14.6 \pm 1.3 \mathrm{~b}$ & 35.4 \\
\hline \multicolumn{4}{|c|}{$24 \mathrm{~h}$ after chinch bug removal } \\
\hline Prestige & $24.6 \pm 2.3 \mathrm{a}$ & $23.0 \pm 3.2 \mathrm{a}$ & 0.07 \\
\hline 378 & $23.1 \pm 1.2 \mathrm{a}$ & $17.7 \pm 1.9 \mathrm{~b}$ & 23.4 \\
\hline \multicolumn{4}{|c|}{$48 \mathrm{~h}$ after chinch bug removal } \\
\hline Prestige & $23.2 \pm 1.7 \mathrm{a}$ & $22.8 \pm 3.2 \mathrm{a}$ & 0.02 \\
\hline 378 & $22.9 \pm 2.9 \mathrm{a}$ & $17.4 \pm 1.6 \mathrm{~b}$ & 24.0 \\
\hline \multicolumn{4}{|c|}{$72 \mathrm{~h}$ after chinch bug removal } \\
\hline Prestige & $22.6 \pm 1.5 \mathrm{a}$ & $21.1 \pm 1.6 \mathrm{a}$ & 0.07 \\
\hline 378 & $21.4 \pm 2.8 \mathrm{a}$ & $16.8 \pm 1.1 b$ & 21.0 \\
\hline
\end{tabular}

Means inthe same row followed by the same letter are not significantly different $(P>0.05$, LSD test).

${ }^{a}$ Percentage of reduction in carbon exchange rates by $B$. occiduus injury relative to the control treatment

intensities, specifically, the photochemical efficiency of the buffalograss plants (Chartier et al. 1970, Sharkey 1985). Light curves at $3 \mathrm{~h}$ after chinch bug removal demonstrated that chinch bug feeding reduces assimilation rates at light intensities $\geq 150 \mu \mathrm{mol}$ of photons $\mathrm{m}^{-2} \mathrm{~s}^{-1}$ (Fig. 3). Chinch bug feeding reduced carbon exchange rates for both buffalograss germplasm; however, the greatest differences in mean carbon exchange rates at the various light intensities were observed for 378. Carbon exchange rates of chinch buginfested 378 plants did not exceed $15 \mu \mathrm{mol} \mathrm{CO} \mathrm{m}^{-2}$ $\mathrm{s}^{-1}$ compared with $22 \mu \mathrm{mol} \mathrm{CO} \mathrm{Cm}^{-2} \mathrm{~s}^{-1}$ for the control plants. Carbon exchange rates were similar for infested and control Prestige plants at the different light intensities at both 3 and $48 \mathrm{~h}$ after chinch bug removal. At $48 \mathrm{~h}$ after chinch bug removal, the greatest differences in mean carbon exchange rates at the various light intensities were observed for 378 plants (Fig. $3)$.

The differences in carbon exchange rates between infested and control buffalograsses, as indicated by the light curves, suggest inefficient photochemical processes in chinch bug-infested 378 plants. Similarities in carbon exchange rates between infested and uninfested Prestige plants indicate that chinch bug feeding has minimal influence on the photochemical efficiency of the plant. Haile et al. (1999) and Ryan et al. (1987) reported, respectively, that Russian wheat aphid, Diuraphis noxia (Mordvilko) and greenbug, Schizaphis graminum (Rondani) injury have similar impacts on carbon exchange rates for wheat.

Information on Rubisco activity and ribulose 1,5bisphosphate regeneration in the dark reaction (Calvin cycle) were depicted by $\mathrm{A}-\mathrm{C}_{\mathrm{i}}$ curves (Farquhar et
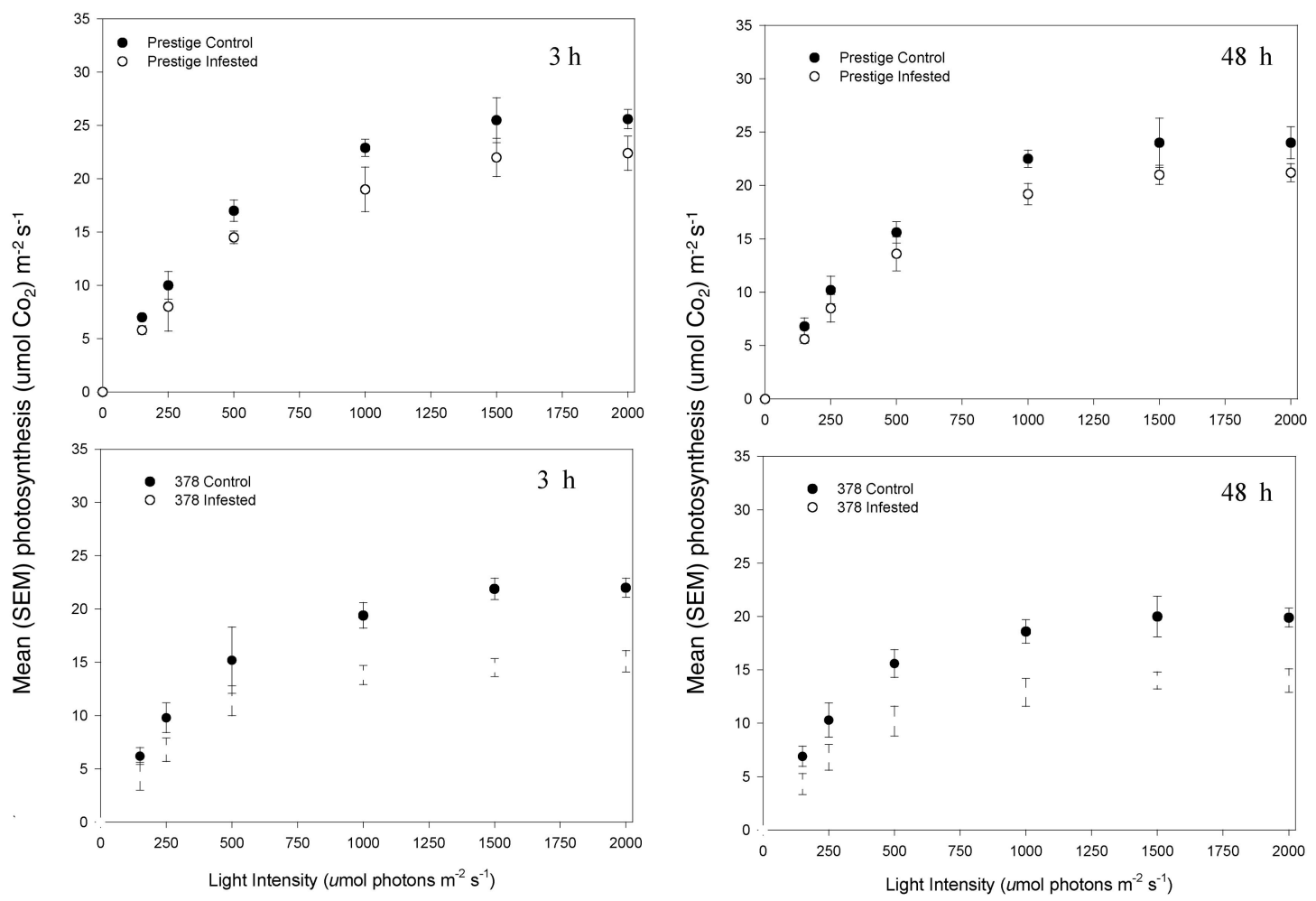

Fig. 3. Relationships between different light intensities and carbon exchange rates (light curves) of buffalograsses. Carbon exchange rates were measured at 3 and $48 \mathrm{~h}$ after chinch bug infestation. 

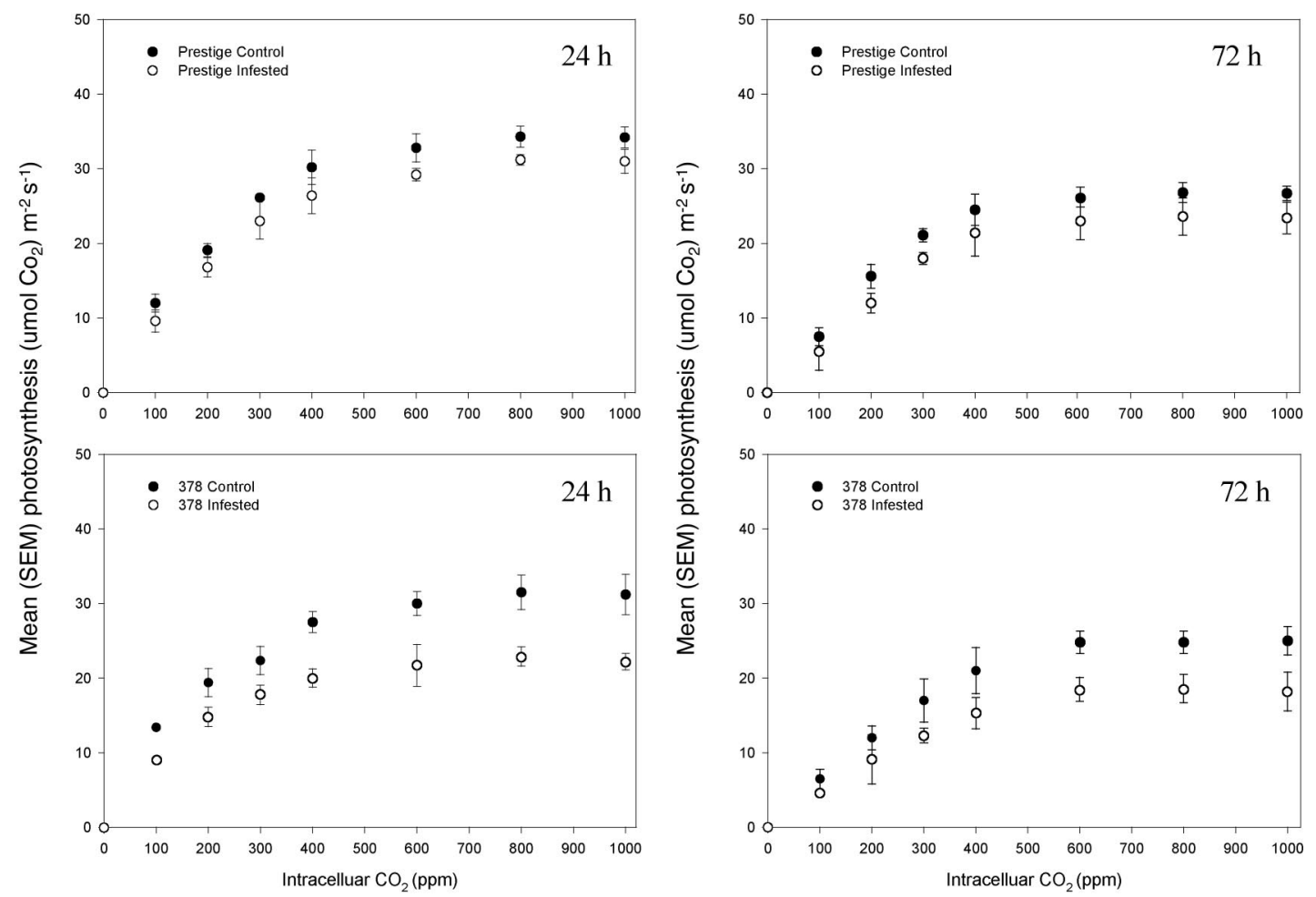

Fig. 4. Relationships between intercellular $\mathrm{CO}_{2}$ concentrations and carbon exchange rates (A-C $\mathrm{C}_{\mathrm{i}}$ curves) of buffalograsses. Carbon exchange rates were measured at 24 and $72 \mathrm{~h}$ after chinch bug infestation.

al. 1980). A- $\mathrm{C}_{\mathrm{i}}$ curves were similar between infested and control Prestige plants at both 24 and $72 \mathrm{~h}$ after chinch bug removal (Fig. 4), indicating that chinch bug feeding did not alter fixation over these time intervals. Infested 378 plants had lower levels of photosynthetic activity at each $\mathrm{CO}_{2}$ concentration compared with their respective controls. These reductions are consistent with photosynthetic reductions resulting from limitations in fixation. Given the absence of strong effects of injury on chlorophyll fluorescence and changes in nonstructural carbohydrates with injury, the results from the $\mathrm{A}-\mathrm{C}_{\mathrm{i}}$ curves support the interpretation that photosynthetic reductions are associated with end product inhibition.

This research provides the first report on the physiological responses of buffalograss to chinch bug feeding and demonstrates that short and long-term changes in photosynthetic compensation could differentiate between resistant and susceptible genotypes. Although the physiological and biochemical mechanisms operating in chinch bug-tolerant buffalograsses are not fully understood, photosynthetic responses suggest chinch bug feeding negatively impacts carbon exchange rates of susceptible buffalograsses through end product inhibition, and photosynthetic compensation occurs in the tolerant buffalograss Prestige.

\section{Acknowledgments}

We thank A. Mascarette Labina, S. Bose, and T. Eickhoff for technical assistance. This research was supported in part by the University of Nebraska Agricultural Experiment Station Project 17-051 and 17-078, the United States Golf Association, and the Nebraska Turfgrass Foundation. This is paper number 14519 of the journal series of the Agricultural Research Division, University of Nebraska-Lincoln.

\section{References Cited}

Baxendale, F. P., T. M. Heng-Moss, and T. P. Riordan. 1999. Blissus occiduus Barber (Hemiptera: Lygaeidae): a new chinch bug pest of buffalograss turf. J. Econ. Entomol. 92: 1172-1176.

Burd, J. D., and N. C. Elliott. 1996. Changes in chlorophyll a fluorescence induction kinetics in cereals infested with Russian wheat aphid (Homoptera: Aphididae). J. Econ. Entomol. 89: 1332-1337.

Chartier, P., M. Chartier, and J. Catskey. 1970. Resistances for carbon dioxide diffusion and for carboxylation as factors in bean leaf photosynthesis. Photosynthetica 4 : $48-57$.

Farquhar, G., S. von Caemmerer, and J. A. Berry. 1980. A biochemical model of photosynthetic $\mathrm{CO}_{2}$ assimilation in leaves of $\mathrm{C}_{3}$ species. Planta 149: 78-90.

Green, T.G.A., B. Schroeter, L. Kappen, R. D. Seppelt, and K. Maseyk. 1998. An assessment of the relationship between chlorophyll $a$ fluorescence and $\mathrm{CO}_{2}$ gas exchange 
from field measurements on a moss and lichen. Planta 206: 611-618.

Haile, F. J., L. G. Higley, X. Ni, and S. S. Quisenberry. 1999. Physiological and growth tolerance in wheat to Russian wheat aphid (Homoptera: Aphididae) injury. Environ. Entomol. 28: 787-794.

Heng-Moss, T. M., F. P. Baxendale, T. P. Riordan, and J. E. Foster. 2002. Evaluation of buffalograss germplasm for resistance to Blissus occiduus. J. Econ. Entomol. 95: 1054-1058.

Heng-Moss, T. M., F. P. Baxendale, T. P. Riordan, L. J. Young, and K. Lee. 2003. Chinch bug resistant buffalograss: an investigation of tolerance, antixenosis, and antibiosis. J. Econ. Entomol. 96: 1942-1951.

Littell, R. C., G. A. Milliken, W. W. Stroup, and R. D. Wolfinger. 1996. SAS system for mixed model. SAS Institute, Cary, NC.

Macedo, T. B. 2003. Physiological responses of plants to piercing-sucking arthropods. Ph.D. dissertation, University of Nebraska, Lincoln, NE.

Macedo, T. B., C. S. Bastos, L. G. Higley, K. R. Ostlie, and S. Madhavan. 2003. Photosynthetic responses of soybean to soybean aphid (Homoptera: Aphididae) injury. J. Econ. Entomol. 96: 188-193.

Peterson, R.K.D., and L. G. Higley. 1993. Arthropod injury and plant gas exchange: current understandings and ap- proaches for synthesis. Trends Agric. Sci. Entomol. 1: 93-100.

Peterson, R.K.D., L. G. Higley, and S. M. Spomer. 1996. Injury by Hyalaphora cecropia (Lepidoptera: Saturniidae) and photosynthetic responses of apple and crabapple. Environ. Entomol. 25: 416-422.

Peterson, R.K.D., L. G. Higley, F. J. Haile, and J.A.F. Barrigossi. 1998. Mexican bean beetle (Coleoptera: Coccinellidae) injury affect photosynthesis of Glycine max and Phaseolus vulgaris. Environ. Entomol. 27: 373-381.

Ryan, J. D., R. C. Johnson, R. D. Eikenbary, and K. W. Dorschner. 1987. Drought/greenbug interactions: photosynthesis of greenbug resistant and susceptible wheat. Crop Sci. 27: 283-288.

SAS Institute. 1997. SAS/STAT software: changes and enhancements through release 6.12. SAS Institute, Cary, NC.

Sharkey, T. D. 1985. Photosynthesis in intact leaves of $\mathrm{C}_{3}$ plants: physics, physiology and rate limitations. Bot. Rev. 51: 53-105.

Somogyi, M. 1952. Notes on sugar determination. J. Biol. Chem. 195: 19-23.

Welter, S. C. 1989. Arthropod impact on plant gas exchange, pp. 135-150. In E. A. Bernays [ed.], Insect-plant interactions, vol. 1. CRC, Boca Raton, FL.

Received 16 May 2005; accepted 19 October 2005 